\title{
Comparison of organic matter in intermittent and perennial rivers of Mediterranean Chile with the support of citizen science
}

\author{
Kate Brintrup ${ }^{1,6,7^{*}}$ (D), Cecilia Amigo ${ }^{2}$, José Fernández ${ }^{2}$, Amparo Hernández ${ }^{2}$, Felipe Pérez ${ }^{3}$, Jorge Félez-Bernal ${ }^{1}$, \\ Andrea Butturini ${ }^{4}$, Katia Saez-Carrillo ${ }^{5}$, Mariela A. Yevenes ${ }^{1,6}$ and Ricardo Figueroa ${ }^{1,6}$
}

\begin{abstract}
Background: Although intermittent rivers account for over half of the global fluvial network and could increase in length and quantity in Mediterranean climates (in response to climate changes), there is little documentation of organic matter input to them. This study was made possible by the cooperation of the Concepción Chiguayante School community and the Explora project (Chile), with the support of citizen science. The aim was to compare coarse particulate organic matter quantities and types in the Lonquén basin.

Methods: Samplings were performed in two perennial rivers and two intermittent rivers. First, the riparian vegetation of the streams was characterized through photointerpretation and subsequently the organic matter accumulated in the selected river beds was quantified and typified. Spearman's correlation was used.

Results: The riparian vegetation was similar in both types of rivers, though significantly greater $(p<0.05)$ plant material accumulation was found in intermittent rivers compared to perennial rivers (1029 and $337 \mathrm{~g} \mathrm{~m}^{-2}$, respectively). Likewise, there was a significant relationship among leaves, smaller organic matter, seeds, herbs and shrubs in intermittent rivers.

Conclusions: The results reveal the importance of the intermittent rivers that were sampled as transitory reservoirs of organic matter with high productive potential, especially in the first flood pulses, when this material is transported downstream.
\end{abstract}

Keywords: Intermittent rivers, Citizen science, Coarse particulate organic matter, Mediterranean climate

\section{Introduction}

The transformation of coarse particulate organic matter $(\mathrm{CPOM})$ into smaller particles and dissolved organic matter is fundamental to sustain all life forms in continental aquatic systems [35] and is considered one of the most important ecosystem processes in the biosphere [40]. Allochthonous terrestrial plant material is the fundamental source of energy and organic matter in both rivers and streams [76]. Its decomposition by means of

\footnotetext{
* Correspondence: katebrintrup@gmail.com

'Faculty of Environmental Sciences and EULA-Chile Center, University of Concepción, P.O. Box 160-C, 4070386 Concepción, Chile

${ }^{6}$ Water Research Center for Agriculture and Mining, University Concepción, P.O. Box 160-C, Concepción, Chile

Full list of author information is available at the end of the article
}

detritivorous macroinvertebrates and microbes [54, 61] releases energy and nutrients, which in turn support the food web, and is a key process in the local, regional and even global carbon cycle $[5,10]$.

Intermittent rivers and ephemeral streams (IRES) have not been considered in the global carbon balance of continental aquatic systems and other biogeochemical processes [24-26]. This exclusion could be a serious failure due to the fact that they are important biogeochemical reactors $[26,48]$ and because recently it has been shown that they can store large amounts of organic matter during dry seasons [20, 25, 32]. In addition, IRES account for more than half of the global fluvial network [1, 48]. For example, they account for $59 \%$ of the total length of 
the rivers in the United States of America [53] and it has been observed that due to anthropogenic pressures such as water extraction, land-use changes and global climate change phenomena $[1,37,45]$, the flows of many perennial rivers are decreasing, extending their dry season and transforming them into intermittent or even ephemeral rivers in the short term [48]. These flow variations can be more drastic in areas with a Mediterranean climate $[1,21,48]$ such as Chile [44, 77], where, according to modeling, the flows of some rivers could decrease by up to $45 \%$ [71].

IRES are characterized by abrupt hydrological changes, with large flows during winter and cessation of flows for days or months in summer. During flow seasons, IRES receive, transport and process organic matter from the drainage basin, as perennial rivers do, whereas dry seasons favor the accumulation of allochthonous organic matter in intermittent river beds [20,50]. This accumulation is related to river morphology, characteristics of the river bed substrates, physical properties of organic matter and hydrology [43, 63]. Thus, surface and underground flows influence the abundance of flora and the types present. For example, streams with deeper groundwater levels have more shrub cover and less forest cover, affecting the production of leaf litter and the concentration of inorganic nitrogen in the soil $[49,68]$.

Organic matter input depends on forest structure, composition and phenology [38]. For example, in Eucalyptus forests, both the input of different types and qualities of leaf litter and nutrient contributions are reduced compared with mixed deciduous forests [11, 52, 58]. Abiotic factors such as rainfall or summer droughts can also influence the quantity and quality of leaf litter [7, $51,66]$, and it has even been proved that latitude is an important predictor of leaf litter quality, which would increase at higher latitudes and decrease toward the equator [9]. Furthermore, a recent study showed the organic matter process is faster at low latitudes [74].

Once organic matter enters rivers, it is chemically and physically transformed [35]. This accumulation and decomposition process is mediated by climate and increases under humid and warm conditions $[2,13,18,25$, 65]. On another note, the physical and chemical defenses of leaves such as waxes and polyphenols can remain active for a long time, preventing decomposition [17, 72]. This leads to diminished CPOM input, affecting the nutrient cycle and productivity of the system [39].

In intermittent rivers, summer water shortages reduce microbial activity, end organic matter leaching and interrupt aquatic macroinvertebrate colonization [48]. By contrast, photodegradation is promoted as a result of increased exposure to the action of ultraviolet radiation and the presence of terrestrial consumers increases [3, 19]. Meanwhile, autumn frost periods could promote the decomposition process and increase the quality of organic matter $[46,51]$. Once the drought is over and the reconnection to the fluvial continuum established, all the material that was accumulated and transformed during the dry phase is mobilized and transported [64]. This organic matter is transformed into an essential source of carbon and nutrients for downstream heterotrophic organisms [48]. During the first flood pulses, excess material can cause adverse effects, such as stress in aquatic biota or eutrophication and hypoxia, which sometimes cause the death of fishes, macroinvertebrates and other aquatic organisms [12, 42]. Therefore, the first flood pulses can cause little understood intermediate disruptions $[16,27,31,59]$, with effects that could be catastrophic and require restorative mechanisms $[21,55,75]$. Disruptions caused by flow variation are more significant in Mediterranean rivers and crucial in the regulation of biotic variables [34]. Furthermore, the number of intermittent rivers will increase over time [1, 48], as will the input of organic matter accumulated in the beds of these rivers [25]. Accumulated organic matter has been recognized as an important source of nutrients [69] and global carbon emissions [25], which until now have been underestimated; more research on this is matter required. Specifically, the studied basin provides diverse ecosystem services to towns and isolated houses located near the studied rivers. Groundwater abstraction is carried out through deep wells for the benefit of the agriculture, animals, villages and the forestry industry. Meanwhile, surface water is directly used by the animals of the people living in the basin. Given the local importance of intermittent rivers in Mediterranean Chile to local economic activities and the biogeochemical importance of organic matter that accumulates in their beds during the dry phase, the objective of this study was to compare the quantities and types of organic matter that accumulates during the dry season in the intermittent and perennial river beds of Mediterranean Chile.

The field sampling, laboratory analysis and preparation of this article were carried out with the support of students from the Concepción Chiguayante School (Chile). Citizen science is a research collaboration that involves the participation of the public in scientific research activities at different levels, since the data collection methodologies are simple and the activities can have significant impacts on the people involved [28, 73]. This approach promotes critical and scientific thinking among the participants and changes perspectives on the natural environment [57]. The present research was performed within the framework of a National Commission for Scientific and Technological Research (CONICYT) EXPLORA project, an initiative created by the Chilean government in 1990 to promote the social dissemination of science and 
technology and strengthen bonds between the scientific community and schools $[60,78]$.

\section{Methodology}

As mentioned, the objective of this study was to compare the quantities and types of organic matter that accumulates during the dry season in intermittent and perennial river beds of Mediterranean Chile.

The Lonquén River basin is located in the dryland of the Coastal Mountains in central Chile ( $36^{\circ} 25^{\prime}$ 59,88" $\left.\mathrm{S} ; 72^{\circ} 42^{\prime} 0^{\prime \prime} \mathrm{E}\right)$. The river is predominantly intermittent, but there are some perennial streams in the basin [30]. The basin has an irregular shape and drains an area of $1075 \mathrm{~km}^{2}$ (Fig. 1). Its geomorphology is heavily weathered and of old relief, with granitic rocks and metamorphic slates. Its soils are eroded, with little permeability and high silt, clay and sand content [30]. The catchment land use comprises mainly forest plantation (Pinus radiata and Eucalyptus globulus) and agricultural monocultures, which are typical of the Mediterranean climate of Chile $[6,33,41]$. The annual average temperature is $14.1{ }^{\circ} \mathrm{C}$ and annual rainfall is $897.9 \mathrm{~mm}$ [30]. The study area rainfall data was collected from the San Agustín de Puñual weather station (code 08118004-0) of the Chilean General Water Directorate (2019) [29] (DGA, for its initials in Spanish).

CPOM larger than $1 \mathrm{~mm}$ was collected by students from the beds of two perennial rivers (Goropeumo and Los Robles) and two intermittent rivers (Las Minas and Arrayán) at the beginning of autumn on May 24, 2017, during the dry phase of the intermittent rivers (Fig. 1). The sampling date was chosen in order to have a maximum of days since senescence and thus the greatest possible CPOM accumulation before the reconnection of the aquatic system. At the time of the sampling, the air temperature was $18{ }^{\circ} \mathrm{C}$ and the intermittent rivers had no water flow, while both perennial rivers had a baseflow of $0.3 \mathrm{~m}^{3} \mathrm{~s}^{-1}$, which was determined using the speed-area method. There was only one sampling season, since the students were involved in Explora CONICYT activities for just one year and the following year the opportunity to participate in another project would be given to a different group of students.

Prior to the collection, students attended three training sessions on intermittent rivers, biogeochemistry and sampling techniques. A section ten times longer than the active average width (see Table 1) of the channel was sampled in order to ensure a consistent sampling effort and obtain representative samples of each reach [47]. To this end, $\mathrm{m}^{2}$ quadrants were used, with collection in at least the $5 \%$ of the entire area; thus, twelve randomly distributed samplings of each reach were carried out [25]. CPOM was collected by hand and stored in properly labeled airtight plastic bags. The types of CPOM collected were leaves, smaller organic matter $\left(\mathrm{CPOM}_{\mathrm{ms}}\right.$, corresponding to $1 \mathrm{~mm}<\mathrm{CPOM}<30 \mathrm{~mm}$ fragments, predominantly pieces of decomposing leaves and plant material), woods, seeds, herbs, shrubs and others (insects and fungi). In the laboratory the wet samples of each СРОM type contained in paper bags were weighed,

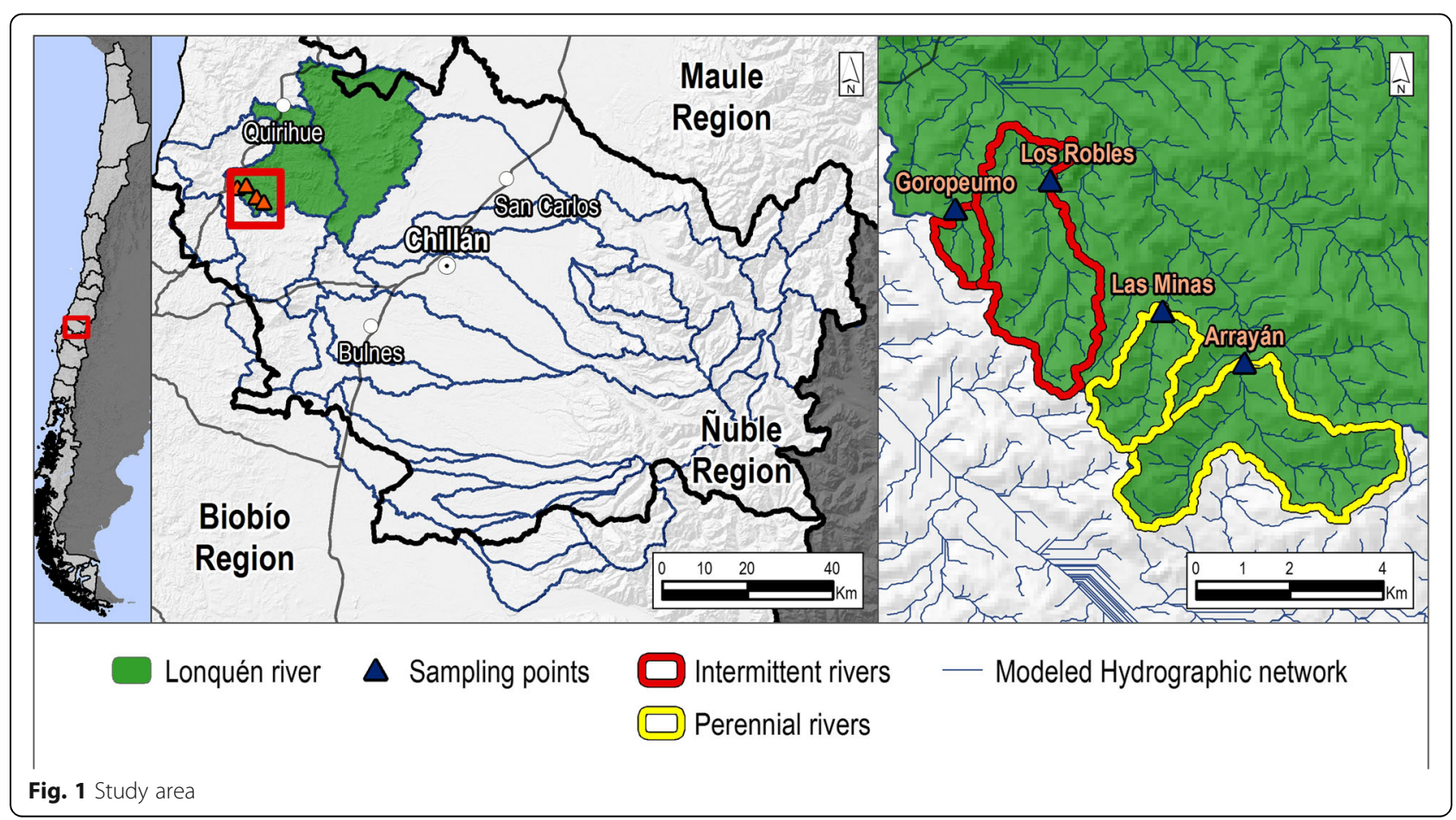


Table 1 Soil use of the microbasins, photointerpretation of the reach, including influence area, and characteristics of the studied riverbeds in the Lonquén river basin

\begin{tabular}{|c|c|c|c|c|c|}
\hline & & Intermittent & & Perennial & \\
\hline & & Goropeumo & Los Robles & Las Minas & Arrayan \\
\hline Land use (\%) & Area (ha) & 135.0 & 954.0 & 378.0 & 1084.0 \\
\hline & Forest plantation & 66.0 & 56.6 & 81.5 & 76.8 \\
\hline & Farming & 0.2 & 27.9 & 1.5 & 15.9 \\
\hline & Shrubs & 33.7 & 12.4 & 12.4 & 4.7 \\
\hline & Native forest & 0.0 & 0.2 & 0.0 & 2.2 \\
\hline & Exotic forest & 0.0 & 2.9 & 4.6 & 0.4 \\
\hline Photointerpretation (\%) & Area (ha) & 3.9 & 6.8 & 3.9 & 3.9 \\
\hline & Agricultural & 49.9 & 52.5 & 42.5 & 53.5 \\
\hline & Exotic wild trees & 30.6 & 17.6 & 11.4 & 27.5 \\
\hline & Exotic monoculture trees & 2.2 & 0.0 & 4.2 & 0.0 \\
\hline & Exotic trees isolated & 1.5 & 1.6 & 2.0 & 0.2 \\
\hline & Exotic trees adult & 0.0 & 11.9 & 0.0 & 0.0 \\
\hline & Exotic shrub (Ulex spp) & 3.1 & 0.0 & 0.0 & 0.0 \\
\hline & Shrubs-matorral & 8.8 & 1.5 & 30.2 & 8.8 \\
\hline & Hygrophilous & 0.2 & 4.1 & 0.0 & 0.0 \\
\hline & Roads & 3.1 & 6.2 & 4.0 & 4.1 \\
\hline & Edification & 0.0 & 1.9 & 2.9 & 1.5 \\
\hline & Fallow land & 0.5 & 2.7 & 2.8 & 4.4 \\
\hline Streambed & Visual coverage of riparian vegetation (\%) & 90.0 & 80.0 & 95.0 & 95.0 \\
\hline & Active channel width (m) & 2.0 & 4.0 & 5.0 & 4.0 \\
\hline & Floodplain width (m) & 10.0 & 10.0 & 10.0 & 7.0 \\
\hline & Silt (\%) & 70.0 & 20.0 & 0.0 & 90.0 \\
\hline & Sand (\%) & 30.0 & 80.0 & 100.0 & 10.0 \\
\hline & CPOM productivity & 0.5 & 0.5 & 0.3 & 0.1 \\
\hline & CPOM moisture (\%) & 50.4 & 45.5 & 47.5 & 40.0 \\
\hline
\end{tabular}

and subsequently the bags were put into a Memmert oven for $48 \mathrm{~h}$. The bags were then weighed again to determine the water content percentage. In order to identify the rivers with greater productive potential, an equation was defined,

$$
\mathrm{CPOM}_{\text {productivity }}=\mathrm{CPOM}_{\mathrm{ms}} / \mathrm{CPOM}_{\text {total }}[1] \text {, }
$$

with values close to 1 indicating greater productive potential of the ecosystem. For the characterization of the study area, the soil uses of each micro-basin were identified and modeled based on data from 2015 provided by CONAF [15] by means of Arcgis 10.1 software. In order to characterize the riparian vegetation of the studied reaches, photointerpretation was used after anchoring, correction and georeferencing of images. A radius of $50 \mathrm{~m}$ around the channel and an area of influence of up to $300 \mathrm{~m}$ upstream of each sampled reach were defined. Thus, the vegetation that could affect the deposition of plant material in the studied reaches was included.
To determine if there were significant differences between CPOM, $\mathrm{CPOM}_{\text {productivity }}$ [1] and soil classifications according to photointerpretation results, the Shapiro \& Wilk normality test was applied, but as the data had a non-normal distribution, the Kruskal-Wallis nonparametric method was used $(p<0.05)$. To examine the relationship between CPOM classifications and moisture in perennial and intermittent rivers, Spearman's correlation was used. All analyses were performed with R software version 3.1.1 using Vegan and Performance Analysis packages.

\section{Results}

Weather data indicated low rainfall during summer: 0 $\mathrm{mm}$ in January, 8.3 in February, $17.7 \mathrm{~mm}$ in March, 26.6 $\mathrm{mm}$ in April and 84.3 in May, prior to the sampling.

According to the characterization of the study area, the predominant land uses in the four micro-basins were forest plantations, followed by shrubs and agriculture 
(70, 15.8 and $11.3 \%$ on average, respectively) (Table 1 , Fig. 1 and Fig. 2), with agriculture predominant along the middle reaches. In accordance with the photointerpretation (Fig. 2), when comparing the soil uses along intermittent and perennial rivers (reach and its influence area included), significant differences were not found $(p>0.05)$.

Regarding CPOM, intermittent rivers accumulated organic matter with higher productive potential for the ecosystem $\left(\mathrm{CPOM}_{\text {productivity, }} p<0.5\right)$ and in greater quantities $\left(1029 \mathrm{~g} \mathrm{~m}^{-2}\right)$ than perennial rivers $\left(337 \mathrm{~g} \mathrm{~m}^{-2}\right.$, $p<0.05$ ) (see Table 1 and Fig. 3). The difference is thought to be due to a larger quantity of leaves, $\mathrm{CPOM}_{\mathrm{ms}}$, seeds, herbs and shrubs in the intermittent rivers. Additionally, no significant differences in wood and other types of organic matter were found $(p>0.05)$. Furthermore, no herbs or shrubs were found along either perennial river (Fig. 3). $\mathrm{CPOM}_{\text {productivity in both }}$ intermittent rivers was identical, as was the case in perennial rivers $(p>0.05)$ (see Table 1).
No relationship between the moisture of the organic matter and the types of CPOM was found in any river. In intermittent rivers, there was a strong relationship ( $p>0.05)$ between different types of organic matter, especially between $\mathrm{CPOM}_{\mathrm{ms}}$ and wood, in contrast to the perennial rivers, in which only a relationship between leaves and $\mathrm{CPOM}_{\mathrm{ms}}$ was observed (Fig. 4).

\section{Discussion}

Low-order rivers drain small hydrographic networks and have narrow channels bordered by abundant riparian vegetation $[35,40,61,79]$. Therefore, organic matter is processed within the channel and transported downstream, where it continues to be processed along the longitudinal profile [76]. However, it also happens that most low-order rivers in Mediterranean climates have intermittent behavior [8] and therefore are crucial in the regulation and processing of organic matter, since the climate and latitude are the key factors that determine the characteristics of the riparian area, type of

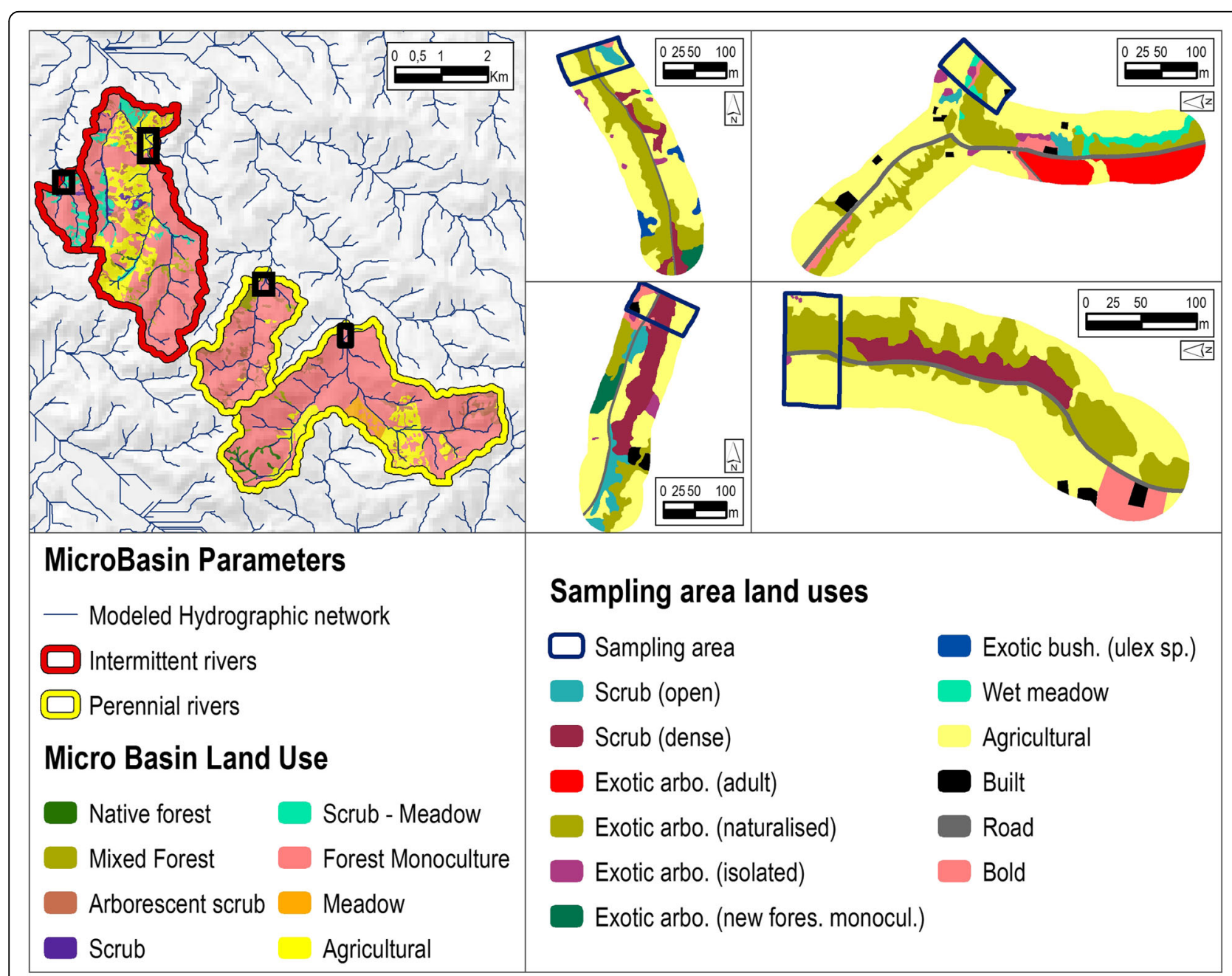

Fig. 2 Soil uses of the microbasins and photointerpretation of the sampled reaches and its influence area [15] 


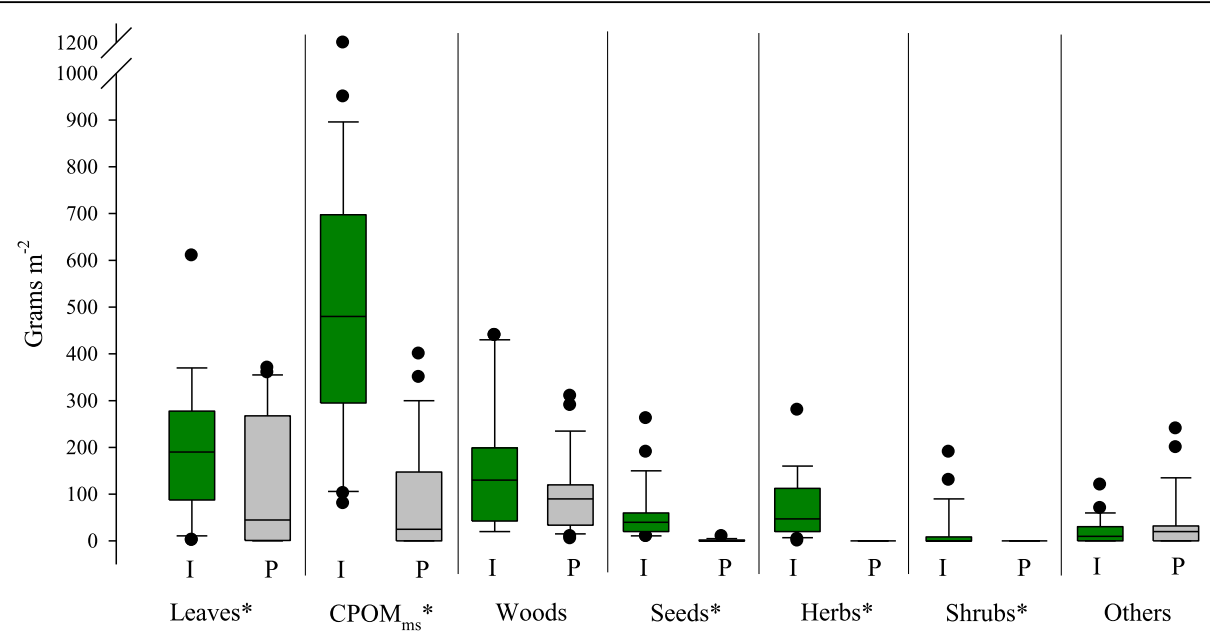

Fig. 3 Coarse particulate organic matter (CPOM) sampled in intermittent rives (I, green color) and perennial rivers ( $P$, gray color), ${ }^{*} p$ value $<0.05$. *The boundary of the box closest to zero indicates the 25th percentile, a line within the box marks the median, and the boundary of the box farthest from zero indicates the 75th percentile. Whiskers (error bars) above and below the box indicate the 90th and 10th percentiles; mean values are shown with a dotted line)

vegetation, flow regime and biomass input [25, 47, 74]. This ultimately impacts the accumulation and decomposition of organic matter [25]. In contrast to perennial rivers, intermittent rivers accumulate this material to a greater extent, subjecting it to photodegradation and/or biodegradation, according to humidity and light conditions in the river bed $[3,19]$.

The results indicated that there was a greater accumulation of CPOM, especially of a smaller size, in intermittent river beds and that it had higher productive potential and more complex relationships with the different types of organic matter, even when the land use of the basins, river order, morphology, substrate, physical properties and vegetation characteristics were similar in both types of rivers. Therefore, the variable that most affected the accumulation of organic matter in this study was hydrology. Similar results were observed by Hoover et al. [43] and Richardson et al. [63]; in these studies, hydrology, river channel characteristics and physical properties of the plant material are involved in CPOM retention and decomposition. In this sense, surface and underground water flow can limit the growth of different types of vegetation [67]. Thus, in the perennial rivers, although they receive allochthonous material, the continuous flow throughout the hydrological year reduced the accumulation of plant material, which made the growth

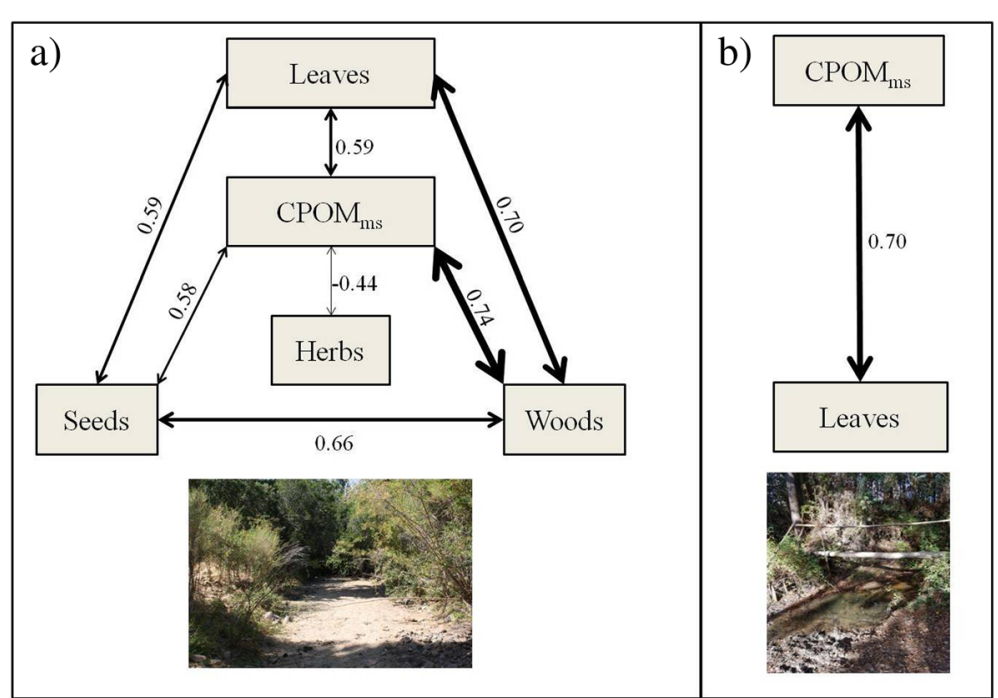

Fig. 4 Relations of the coarse particulate organic matter in intermittent (a) and perennial (b) rivers. *Arrows and numbers indicate significant relation and $r$ value, respectively 
of herbs and shrubs in the river bed impossible, limiting the relationships among types of organic matter. The accumulation of plant material was highly dependent on the leaves provided by riparian vegetation that can decompose and generate bioavailable organic matter. This took place through processes that include biotic factors, such as benthic macroinvertebrates, bacteria and other physical factors that are related to geomorphology (for example, pools and riffles), water velocity in the reach and even climate and latitude [22, 23, 25, 74, 76].

The studied reaches in the intermittent and perennial rivers presented high CPOM moisture (ca. 50\%) and high riparian coverage, which promoted the generation of shade in the river bed. These conditions favored bacterial decomposition of organic matter in the intermittent rivers during the season without flows, which was also favored by rainfall prior to sampling. Moisture can be maintained in piles of wood and CPOM, predominantly of larger sizes [56]. In addition, in the intermittent rivers there was a higher amount of CPOM and decomposing organic matter, even though based on a visual examination there appeared to be a greater percentage of riparian coverage in the perennial reaches and the photointerpretation analyses indicated a similar soil use classification (Fig. 2). This showed that intermittent rivers follow other biogeochemical pathways than those described in classical processes, since water flow transports solutes and particulate organic matter downstream and toward the coastal area, especially in the first flood pulses [25], and then acts as a longitudinal biogeochemical reactor that rapidly processes this material, as Vannote et al. [76] describe. However, particularly in intermittent rivers, bacteria that are involved in processing are highly adapted to extreme water conditions and to the cessation of flow/rewetting [4, 70]. During droughts, meanwhile, most of the little processing in river beds is mediated by photodegradation, and there is isolated processing in pools by macroinvertebrates and microbial activity [48]. Therefore, biological participation is high (e.g., microorganisms and shredder macroinvertebrates), since intermittent rivers are critical sites for the accumulation of organic matter that has the potential to generate large-scale point pulses downstream in the first flood pulse, as well as high emissions of $\mathrm{CO}_{2}$ into the atmosphere. For example, $[25,64]$ found up to $13 \mathrm{~g} \mathrm{~m}^{-2}$ $\mathrm{d}^{-1} \mathrm{CO}_{2}$ emissions into the atmosphere. The Mediterranean IRES of central Chile sampled in this study were included in the 1000 Intermittent Rivers project [25].

In summer and autumn periods without flows, the transformation of organic matter slows and the material accumulates [3, 32]. Consequently, this material with low processing rates and higher-quantity labile and bioavailable matter [20] is exported to the watercourse when the flow of the rivers restarts [19, 48, 62], a phenomenon that was studied by Casas-Ruíz et al. [14] to determine when the river acted as an active reactor or passive tubing in the processing of dissolved organic matter. The opposite takes place in perennial rivers, which transport organic material from the riparian vegetation with low levels of processing and continuous CPOM renewal.

According to the results of previous studies [3, 7, 19, 51, 66], drought affected both the decomposition and quality of organic matter due to a higher carbon:nitrogen molar ratio in the leaf litter, a decrease in microbial activity and an interruption of organic matter colonization, and in the IRES studied, it is assumed that the summer drought of 2017 also affected the accumulated CPOM. Despite this phenomenon, a large amount of decomposing organic matter was found, probably associated with the moisture content of the samples after a wet autumn [2, 36, 46, 51, 65]. This, together with the latitude of the rivers, favors the formation of good quality organic matter. In a global study, Boyero et al. [9] found that in the tropics leaf litter is of lower quality and phosphorous is limiting, which restricts decomposition by detritivores, unlike what happens at higher latitudes. Therefore, the results indicate, on one hand, the importance of IRES in the functioning of aquatic ecosystems during the first flood pulses and indicates the high potential of these rivers as a source of carbon, organic matter and energy for the productivity of the ecosystem $[35,39,61]$. On the other hand, perennial rivers accumulate less allochthonous organic matter and transport it continuously, which is important at critical moments (spring-summer) when high energy inputs are required.

IRES should be analyzed in a climate change context, since these rivers are increasingly expanding in both length and area $[1,37,48]$. What is more, perennial rivers are at risk of undergoing hydrology and water quality modifications $[71,77,80]$ and thus of becoming intermittent. The results of this study, the first in the region, were consistent, although further data are required, and the support of the public may prove important. There is great interest in Chile in science- and technology-related environmental issues, but both the dissemination of technoscientific knowledge and understanding of the scientific method are deficient $[60,78]$. Therefore, it is essential to promote initiatives that involve science and citizens. This study acquainted students with the scientific method, enabling them to view intermittent rivers not as temporarily dead systems, but rather as systems of local and global importance in the ecosystem. Students shared their results and what they learned in the Provincial and Regional Science and Technology Congress organized by EXPLORA (CONICYT) and in the National Science and Technology Fair at Biobío University, Chile. 


\section{Conclusions}

Intermittent rivers can accumulate greater quantities of CPOM with a higher productive potential than perennial rivers. According to previous studies, the organic matter that accumulates generates downstream nutrient emissions and $\mathrm{CO}_{2}$ emissions into the atmosphere in the first flood pulses. In addition, more than half of the global fluvial network is made up of intermittent rivers and it is predicted that they will increase in quantity and length, especially in areas with a Mediterranean climate. Therefore, it is important to study the amount and type of CPOM that these rivers can accumulate to determine the consequences of the first flood pulses. Research in larger geographical areas in collaboration with citizens, to foster a deeper knowledge of intermittent rivers, is recommended.

\section{Abbreviations}

CONICYT: National Commission for Scientific and Technological Research; CPOM: coarse particulate organic matter; IRES: intermittent rivers and ephemeral streams

\section{Acknowledgements}

The authors would like to thank the Water Research Center for Agriculture and Mining (CHRIAM), the General Water Directorate Chile (DGA), Doctoral scholarship in Chile N²1130128, CONICYT/FONDAP/15130015, EXPLORA Biobío Project (CONICYT), the school community and teachers of the Concepción Chiguayante School for their interest, and thank to Peter Lewis, María Zenteno Arzola (translator) and Barret Buchholz for his revision of the English text and comments.

\section{Authors' contributions}

$\mathrm{KB}, \mathrm{CA}$, JF-B and $\mathrm{AH}$ contributed to the design of the work, sampling, analysis, interpretation of results and writing of the work. KS-C and JF-B analyzed and interpreted the statistical and geospatial data, respectively. FP, $A B, M Y$ and RF reviewed the work and participated in the writing. All authors read and approved the final manuscript and have agreed to be personally responsible for their own contributions.

\section{Funding}

Water Research Center for Agriculture and Mining (CHRIAM), Doctoral scholarship in Chile N²1130128, CONICYT/FONDAP/15130015 and EXPLORA Biobío Project (CONICYT).

\section{Availability of data and materials}

The datasets used and/or analyzed during the current study are available from the corresponding author upon reasonable request.

\section{Ethics approval and consent to participate}

Not applicable.

\section{Consent for publication}

Not applicable.

\section{Competing interests}

The authors declare that they have no competing interests.

\section{Author details}

${ }^{1}$ Faculty of Environmental Sciences and EULA-Chile Center, University of Concepción, P.O. Box 160-C, 4070386 Concepción, Chile. ${ }^{2}$ Concepción Chiguayante School, 4100223 Chiguayante, Chile. ${ }^{3}$ Facultad de Ingeniería, Universidad Andrés Bello, Autopista Concepción-Talcahuano s/n, 4260000 Talcahuano, Chile. ${ }^{4}$ Departament Ecologia Evolutiva i Ciencie Ambientals, Universitat de Barcelona, Barcelona, Spain. ${ }^{5}$ Facultad de Ciencias Físicas y Matemáticas, Departamento de Estadística, Universidad de Concepción, P.O. Box 160-C, Concepción, Chile. ${ }^{6}$ Water Research Center for Agriculture and Mining, University Concepción, P.O. Box 160-C, Concepción, Chile. ${ }^{7}$ Facultad de Ingeniería y Tecnología, Universidad San Sebastián, Lientur 1457, 4080871 Concepción, Chile.

Received: 13 March 2019 Accepted: 16 June 2019

Published online: 05 July 2019

\section{References}

1. Acuña V, Datry T, Marshall J, Barceló D, Dahm CN, Ginebreda A, McGregor G, Sabater S, Tockner K, Palmer MA. Why should we care about temporary waterways? Science. 2014;343(6175):1080-1. https://doi.org/10.1126/science. 1246666.

2. Aerts R. Climate, leaf litter chemistry and leaf litter decomposition in terrestrial ecosystems: a triangular relationship. Oikos. 1997;79:439-49. https://doi.org/10.2307/3546886.

3. Austin AT, Vivanco L. Plant litter decomposition in a semi-arid ecosystem controlled by photodegradation. Nature. 2006;442:555-8. https://doi.org/10. 1038/nature05038.

4. Austin AT, Yahjian L, Stark JM, Belnap J, Porporato A, Norton U, Ravetta DA, Schaeffer SM. Water pulses and biogeochemical cycles in arid and semiarid ecosystems. Oecologia. 2004;142:221-35.

5. Battin TJ, Luyssaert S, Kaplan LA, Aufdenkampe AK, Richter A, Tranvik LJ. The boundless carbon cycle. Nat Geosci. 2009;2:598-600. https://doi.org/10.1038/ ngeo618.

6. Becerra PI. Relationship between climate and geographical variation of local woody species richness within the Mediterranean-type region of Chile. Rev Chil Hist Nat. 2016:89:12. https://doi.org/10.1186/s40693-016-0062-x.

7. Benfield EF. Comparison of litterfall input to streams. J N Am Benthol Soc. 1997;16:104-8. https://doi.org/10.2307/1468242.

8. Benstead JP, Leigh DS. An expanded role for river networks. Nat Geosci. 2012:5:678-9. https://doi.org/10.1038/ngeo1593.

9. Boyero L, Graça MA, Tonin AM, Pérez J, Swafford AJ, Ferreira V, et al. Riparian plant litter quality increases with latitude. Sci Rep. 2017;7:10562. https://doi.org/10.1038/s41598-017-10640-3.

10. Boyero L, Pearson RG, Gessner MO, Barmuta LA, Ferreira V, Graça MA, et al. A global experiment suggests climate warming will not accelerate litter decomposition in streams but might reduce carbon sequestration. Ecol Lett. 2011;14:289-94. https://doi.org/10.1111/j.1461-0248.2010.01578.x.

11. Bunn SE. Processing of leaf litter in a northern jarrah forest stream, Western Australia: I. seasonal differences. Hydrobiologia. 1988;162:201-10.

12. Bunn SE, Thoms MC, Hamilton SK, Capon SJ. Flow variability in dryland rivers: boom, bust and the bits in between. River Res Appl. 2006;22:179-86. https://doi.org/10.1002/rra.904.

13. Campeche $E_{1}$ Pérez M, Nava V, Valencia U, López R, Payan F. Producción de $\mathrm{CO}_{2}$ en el suelo por la adición de mezclas microbianas y residuos de poda de Acacia retinodes (Fabales: Fabaceae). Interciencia. 2018;43(13):836-40.

14. Casas-Ruiz JP, Catalán N, Gómez-Gener L, von Schiller D, Obrador B, Kothawala DN, López P, Sabater S, Marcé R. A tale of pipes and reactors: controls on the in-stream dynamics of dissolved organic matter in rivers. Limnol Oceanogr. 2017;62:S85-94. https://doi.org/10.1002/Ino.10471.

15. CONAF. Departamento de Monitoreo de Ecosistemas Forestales, Santiago, Chile. Monitoreo de cambios, corrección cartográfica y actualización del catastro de los recursos vegetacionales nativos de la Región del Biobío. Informe Técnico. 2017; 74. Santiago, Chile. https://biblioteca.digital.gob.cl/ bitstream/handle/123456789/2336/Informe\%20Catastro\%20recursos\% 20vegetacionales\%20nativos\%2008REG\%202017.pdf? sequence= 1 \&isAllowed=y. Accessed 20 Sept 2018.

16. Connell JH. Diversity in tropical rain forests and coral reefs. Science. 1978; 199:1302-10. https://doi.org/10.1126/science.199.4335.1302.

17. Coq S, Souquet JM, Meudec E, Cheynier V, Hattenschwiler S. Interspecific variation in leaf litter tannins drives decomposition in a tropical rain forest of French Guiana. Ecology. 2010;91:2080-91. https://doi.org/10.1890/091076.1 .

18. Cornwell WK, Cornelissen JH, Amatangelo K, Dorrepaal E, Eviner VT, Godoy $\mathrm{O}$, et al. Plant species traits are the predominant control on litter decomposition rates within biomes worldwide. Ecol Lett. 2008;11:1065-71. https://doi.org/10.1111/j.1461-0248.2008.01219.x.

19. Corti R, Datry T. Invertebrates and sestonic matter in an advancing wetted front travelling down a dry river bed (Albarine, France). Freshw. Sci. 2012;31: 1187-201. https://doi.org/10.1899/12-017.1.

20. Corti R, Datry T, Drummond L, Larned S. Natural variation in immersion and emersion affects breakdown and invertebrate colonization of leaf litter in a 
temporary river. Aquat Sci. 2011;73:537-50. https://doi.org/10.1007/s00027011-0216-5.

21. Creed IF, Lane CR, Serran JN, Alexander LC, Basu NB, Calhoun ABJK, et al. Enhancing protection for vulnerable waters. Nat Geosci. 2017;10:809-15. https://doi.org/10.1038/ngeo3041.

22. Cummins KW, Minshall GW, Sedell JR, Cushing CE, Petersen RC. Stream ecosystem theory. Verh Int Ver Limnol. 1984;22:1818-27.

23. Cummins KW, Spengler GL, Ward GM, Speaker RM, Ovink RW, Mahan DC. Processing of confined and naturally entrained leaf litter in a woodland stream ecosystem. Limnol Oceanogr. 1980;25:952-7. https://doi.org/10.4319/ lo.1980.25.5.0952.

24. Datry T, Corti R, Foulquier A, von Schiller D, Tockner T. One for all, all for one: a global river research network. Eos. 2016;97:13-5. https://doi.org/10. 1029/2016EO053587.

25. Datry T, Foulquier A, Corti R, von Schiller D, Tockner K, Mendoza-Lera C, et al. A global analysis of terrestrial plant litter dynamics in non-perennial waterways. Nat Geosci. 2018;11:497-503. https://doi.org/10.1038/s41561018-0134-4.

26. Datry T, Larned ST, Tockner K. Intermittent rivers: a challenge for freshwater ecology. BioScience. 2014;64:229-35. https://doi.org/10.1093/biosci/bit027.

27. Dayton PK. Competition, disturbance, and community organization: the provision and subsequent utilization of space in a rocky intertidal community. Ecol Monogr. 1971;41:351-89. https://doi.org/10.2307/1948498.

28. Dickinson JL, Bonney R, Fitzpatrick JW. Overview of Citizen Science. (Eds.), Citizen science: public participation in environmental research. Ithaca: Comstock; 2015

29. Chilean General Water Directorate. Meteorological database. http://snia.dga. cl/BNAConsultas/reportes. Accessed 30 april 2019.

30. Duissaillant A. Hidrología de la cuenca del río Itata. In: Parra, O., Castilla. J.C., Romero, H., Quiñones, R., Camaño, A. (eds.). La cuenca hidrográfica del río Itata: aportes científicos para su gestión. Ediciones Universidad de Concepción; 2009; p. 27-43.

31. Flecker AS, Feifareck B. Disturbance and the temporal variability of invertebrate assemblages in two Andean streams. Freshw Biol. 1994;31(2): 131-42. https://doi.org/10.1111/j.1365-2427.1994.tb00847.x.

32. Foulquier A, Artigas J, Pesce S, Datry T. Drying responses of microbial litter decomposition and associated fungal and bacterial communities are not affected by emersion frequency. Freshw Sci. 2015;34:1233-44. https://doi. org/10.1086/682060.

33. Garfias R, Castillo M, Ruiz F, Vita A, Bown H, Navarro R. Remanentes del bosque esclerófilo en la zona Mediterránea de Chile central; caracterización y distribución de fragmentos. Interciencia. 2018;43(9):655-63.

34. Gasith A, Resh VH. Streams in Mediterranean climate regions: abiotic influences and biotic responses to predictable seasonal events. Annu Rev Ecol Syst. 1999;30:51-81. https://doi.org/10.1146/annurev.ecolsys.30.1.51.

35. Gessner MO, Chauvet E, Dobson M. A perspective on leaf litter breakdown in streams. Oikos. 1999:85:377-84. https://doi.org/10.2307/3546505.

36. Gholz H, Wedin D, Smitherman SM, Harmon ME, Parton WJ. Long-term dynamics of pine and hardwood litter in contrasting environments: toward a global model of decomposition. Glob Chang Biol. 2000;6:751-65. https:// doi.org/10.1046/j.1365-2486.2000.00349.x.

37. Gleick PH. Global freshwater resources: soft-path solutions for the 21st century. Science. 2003;302(5650):1524-8. https://doi.org/10.1126/science.1089967.

38. González L, Acosta M, Carrillo F, Rueda A. Simulación de los cambios de carbono orgánico del suelo en especies tropicales con el modelo ROTHC 26.3. Interciencia. 2018;43(4):268-74.

39. Graça M, Ferreira V, Canhoto C, Encalada A, Guerrero-Bolaño F, Wantzen K, Boyero L. A conceptual model of litter breakdown in low order streams. Int Rev Hydrobiol. 2015;100:1-12. https://doi.org/10.1002/iroh.201401757.

40. Hasler CT, Butman D, Jeffrey JD, Suski CD. Freshwater biota and rising pCO2? Ecol Lett. 2016;19(1):98-108. https://doi.org/10.1111/ele.12549.

41. Hernández A, Miranda M, Arellano E, Dobbs C. Landscape trajectories and their effect on fragmentation for a Mediterranean semi-arid ecosystem in Central Chile. J Arid Environ. 2016;127:74-81. https://doi.org/10.1016/j. jaridenv.2015.10.004

42. Hladyz S, Watkins SC, Whitworth KL, Baldwin DS. Flows and hypoxic Blackwater events in managed ephemeral river channels. J Hydrol. 2011;401: 117-25. https://doi.org/10.1016/j.jhydrol.2011.02.014.

43. Hoover TM, Richardson JS, Yonemitsu N. Flow-substrate interactions create and mediate leaf litter resource patches in streams. Freshw Biol. 2006;51: 435-47. https://doi.org/10.1111/j.1365-2427.2005.01499.x.
44. IPCC. Climate change 2014: impacts, adaptation, and vulnerability Cambridge: Contribution of Working Group II to the Fifth Assessment Report of the Intergovernmental Panel on Climate Change. Cambridge University Press; 2014.

45. Jaeger KL, Olden JD, Pelland NA. Climate change poised to threaten hydrologic connectivity and endemic fishes in dryland streams. Proc Natl Acad Sci U S A. 2014;111:13894-9. https://doi.org/10.1073/pnas.1320890111.

46. Keskitalo J, Bergquist G, Gardeström P, Jansson S. A cellular timetable of autumn senescence. Plant Physiol. 2005;139:1635-48. https://doi.org/10. 1104/pp.105.066845.

47. Lamberti GA, Entrekin SA, Griffiths NA, Tiegs SD. Coarse particulate organic matter: storage, transport, and retention. In: Lamberti GA, Hauer FR, editors. Methods in stream ecology: volume 2: ecosystem function. Elsevier, academic press; 2017. p. 55-69.

48. Larned ST, Datry T, Arscott DB, Tockner K. Emerging concepts in temporaryriver ecology. Freshw Biol. 2010;55:717-38. https://doi.org/10.1111/j.13652427.2009.02322.x

49. Lite SJ, Stromberg J. Surface water and ground-water thresholds for maintaining Populus-Salix forests, San Pedro River, Arizona. Biol Conserv. 2005;125(2):153-67. https://doi.org/10.1016/j.biocon.2005.01.020.

50. Maamri A, Chergui H, Pattee E. Allochthonous input of coarse particulate organic matter to a Moroccan mountain stream. Acta Oecol. 1994;15:495508. https://doi.org/10.1051/limn/1994024.

51. Marchin R, Zeng H, Hoffmann W. Droughtdeciduous behavior reduces nutrient losses from temperate deciduous trees under severe drought. Oecologia. 2010;163:845-54. https://doi.org/10.1007/s00442-010-1614-4.

52. Molinero J, Pozo J, Gonzalez E. Litter breakdown in streams of the Agüera catchment: influence of dissolved nutrients and land use. Freshw Biol. 1996; 36:745-56. https://doi.org/10.1046/j.1365-2427.1996.00125.x.

53. Nadeau TL, Rains MC. Hydrological connectivity between headwater streams and downstream waters: how science can inform policy. Hydrol Process. 2007:43:118-33. https://doi.org/10.1111/j.1752-1688.2007.00010.x.

54. Naiman RJ, Décamps H. The ecology of interfaces: riparian zones. Annu Rev Ecol Syst. 1997;28:621-58. https://doi.org/10.1146/annurev.ecolsys.28.1.621.

55. Obermann M, Rosenwinkel KH, Tournoud MG. Investigation of first flushes in a medium-sized Mediterranean catchment. J Hydrol. 2009:373:405-15. https://doi.org/10.1016/j.jhydrol.2009.04.038.

56. Pettit NE, Latterell JJ, Naiman RJ. Formation, distribution and ecological consequences of flood-related wood debris piles in a bedrock confined river in semiarid South Africa. River Res Applic. 2006;22:1097-110. https:// doi.org/10.1002/rra.959.

57. Phillips T, Boney R, Shirk J. What is our impact?: toward a unified framework for evaluating outcomes of citizen science participation. In; Bonney $\mathrm{JL}$, Fitzpatrick JW. (Eds.), citizen science: public participation in environmental research. Ithaca: Comstock; 2015.

58. Pozo J, Gonzalez E, Diez JR, Molinero J, Elosegui A. Inputs of particulate organic matter to streams with different riparian vegetation. J N Am Benthol Soc. 1997;16:602-11. https://doi.org/10.2307/1468147.

59. Prat N, González G, Millet X. Comparación crítica de dos índices de calidad del agua. ISQA y BILL. Artículos técnicos, vol. 31; 1986. p. 33-49.

60. Prenafeta S. La comunicación de la ciencia en Chile, Santiago: Conicyt. Chile; 2008.

61. Raymond PA, Hartmann J, Lauerwald R, Sobek S, McDonald C, Hoover M, et al. Global carbon dioxide emissions from inland waters. Nature. 2013;503: 355-9. https://doi.org/10.1038/nature12760.

62. Raymond PA, Saiers JE, Sobczak WV. Hydrological and biogeochemical controls on watershed dissolved organic matter transport: pulse-shunt concept. Ecology. 2016;97:5-16. https://doi.org/10.1890/14-1684.1S.

63. Richardson JS, Hoover TM, Lecerf A. Coarse particulate organic matter dynamics in small streams: towards linking function to physical structure. Freshw Biol. 2009;54:2116-26. https://doi.org/10.1111/j.1365-2427.2009.02279x.

64. Rosado J, Morais M, Tockner K. Mass dispersal of terrestrial organisms during first flush events in a temporary stream. River Res Appl. 2015;31:912-7. https://doi.org/10.1002/rra.2791.

65. Salinas N, Malhi Y, Meir P, Silman M, Roman C, Huaman J, et al. The sensitivity of tropical leaf litter decomposition to temperature: results from a large-scale leaf translocation experiment along an elevation gradient in Peruvian forests. New Phytol. 2011;189:967-77. https://doi.org/10.1111/j. 1469-8137.2010.03521.x.

66. Sanpera-Calbet I, Acuña V, Butturini A, Marcé R, Muñoz I. El Niño southern oscillation and seasonal drought drive riparian input dynamics in a 
Mediterranean stream. Limnol Oceanogr. 2016;61:214-26. https://doi.org/10. 1002/Ino.10211.

67. Shafroth P, Stromberg J, Patten D. Woody riparian vegetation response to different alluvial water table regimes. Western North American Naturalist. 2000;60(1):66-76.

68. Shah JJ, Dahm CN. Flood regime and leaf fall determine soil inorganic nitrogen dynamics in semiarid riparian forests. Ecol Appl. 2008;18:771-88. https://doi.org/10.1890/07-0447.1.

69. Shumilova O, Zak D, Datry T, von Schiller D, Corti R, Foulquier A, et al. Simulating rewetting events in intermittent rivers and ephemeral streams: A global analysis of leached nutrients and organic matter. Glob Change Biol. 2019:1-21. https://doi.org/10.1111/gcb.14537.

70. Sponseller RA. Precipitation pulses and soil $\mathrm{CO}_{2}$ flux in a Sonoran Desert ecosystem. Glob Chang Biol. 2007;13:426-36. https://doi.org/10.1111/j.13652486.2006.01307.x.

71. Stehr A, Debels P, Arumí JL, Alcayaga H, Romero F. Modelación de la respuesta hidrológica al cambio climático: experiencias de dos cuencas de la zona centro-sur de Chile. Tecnología y. Ciencias del Agua. 2010;1 (4):37-58.

72. Stout J. Effects of condensed tannins on leaf processing inmid-latitude and tropical streams: a teoretical approach. CanJ Fish Aquat Sci. 1989;46:1097106. https://doi.org/10.1139/f89-142

73. Tejeda I, Medrano F. El potencial de la ciencia ciudadana para el estudio de las aves urbanas en Chile. Revista Diseño Urbano \& Paisaje. 2018;33:59-66.

74. Tiegs SD, Costello DM, Isken MW, Woodward G, Mclntyre PB, Gessner MO et al. Global patterns and drivers of ecosystem functioning in rivers and riparian zones. Sci Adv. 2019;5:eaav0486. https://doi.org/10.1126/sciadv. aav0486.

75. Tzoraki O, Nikolaidis NP, Amaxidis Y, Skoulikidis NT. Instream biogeochemical processes of a temporary river. Environ Sci Technol. 2007; 41:1225-31. https://doi.org/10.1021/es062193h.

76. Vannote RL, Minshall GW, Cummins KW, Sedell JR, Cushing CE. The river continuum concept. Can J Fish Aquat Sci. 1980;37(1):130-7. https://doi.org/ 10.1139/f80-017.

77. Vicuña S, McPhee J, Garreaud RD. Agriculture vulnerability to climate change in a snowmelt-driven basin in semiarid Chile. J Water Resour Plan Manag. 2012;138:431-41. https://doi.org/10.1061/(ASCE)WR.1943-5452. 0000202.

78. Villarroel P, Valenzuela V, Vergara G, Sepúlveda C. Comprensión pública de la ciencia en Chile: adaptación de instrumentos y medición. Convergencia Revista de Ciencias Sociales. 2013;20(63):13-40.

79. Webster JR, Meyer JL. Organic matter budgets for streams: a synthesis. J N Am Benthol Soc. 1997;16:141-61. https://doi.org/10.2307/1468247.

80. Yevenes M, Figueroa R, Parra O. Seasonal drought effects on the water quality of the Biobío River, Central Chile. Environ Sci Pollut Res. 2018;25(14): 13844-56. https://doi.org/10.1007/s11356-018-1415-6.

\section{Publisher's Note}

Springer Nature remains neutral with regard to jurisdictional claims in published maps and institutional affiliations.

\section{Ready to submit your research? Choose BMC and benefit from:}

- fast, convenient online submission

- thorough peer review by experienced researchers in your field

- rapid publication on acceptance

- support for research data, including large and complex data types

- gold Open Access which fosters wider collaboration and increased citations

- maximum visibility for your research: over $100 \mathrm{M}$ website views per year

At $\mathrm{BMC}$, research is always in progress.

Learn more biomedcentral.com/submissions 